\title{
Impact of Watershed Interventions on Biophysical and Ecosystem Services in Mettur Catchment of Tamil Nadu, India
}

\author{
S. Manivannan ${ }^{1 *}$, O. P. S. Khola ${ }^{2}$, K. Kannan ${ }^{1}$ and V. Kasthuri Thilagam ${ }^{1}$ \\ ${ }^{1}$ ICAR-Indian Institute of Soil and Water Conservation, Research Centre, \\ Udhagamandalam, Tamil Nadu, India \\ ${ }^{2}$ ICAR - Indian Institute of Soil and Water Conservation, Research Centre, Chandigarh, India \\ *Corresponding author
}

\section{A B S T R A C T}

\section{Keywords}

Watershed

Interventions,

Biophysical and

Ecosystem Services

Article Info

Accepted:

15 December 2020

Available Online:

10 January 2021
The impact of comprehensive interventions in checking soil erosion, improving water availability, development of agro-forestry, sustainable management of natural resources, enhancement of agricultural productivity and socio-economic aspects of the farmers of watershed interventions implemented under River Valley Project (RVP) in 149 micro watersheds of Mettur reservoir catchment of Tamil Nadu has been studied through random evaluation of 22 sample watersheds. The results shows that the drainage line treatments made their impacts in terms of arresting silts at the rate of about 12.6 cum $\mathrm{yr}^{-1}$ per watershed. Surface runoff was found to be 4.5 to 5.6 per cent of the rainfall for selected rainfall events. Based on silt deposited behind selected check dams / ponds, soil loss was estimated to vary in the range of 2.3 to $3.51 \mathrm{t} \mathrm{ha}^{-1} \mathrm{yr}^{-1}$, which is very well within the permissible limit. Further, the study revealed that the net present value of the project was more than Rs. 943 crore with $1.75: 1$ BCR and 68 per cent IRR which proves that the project was technically feasible and economically viable. Though the project has made positive impact in the project area, it lacks required convergence and linkages with the line departments such as Agriculture, Horticulture, Rural Development and Forestry which suggests that during the phasing out stage, strong linkages should be developed with these departments to integrate the various developmental schemes with this project and ensure sustainability after its withdrawal.

\section{Introduction}

About $65 \%$ of arable land in Indian agriculture is rainfed with high risk and uncertainty due to vagaries in monsoon, low soil fertility, low level of technological adoptions which leads to very low productivity (NAAS 2009). The productivity of rainfed areas ranges between 0.5 and 2.0 ton $\mathrm{ha}^{-1}$ (Rockstrom et al., 2010; Wani et al., 2011). In comparison with rainfed agriculture, irrigated agriculture in India has attainted its maximum productivity (CWC, 2005). Further increase in food production must be contributed from rainfed agriculture and this calls for an analysis of situations under which watershed technology becomes economically viable, socially acceptable and ecologically 
sustainable (Reddy, 2000). The soil and water conservation measures implemented in the fields, effectively reduce onsite soil loss and sediment yield through Integrated small watershed management (Shi et al., 2012). According to Serveiss (2002) integrating the watershed approach with ecological risk assessment increases the use of environmental monitoring and data assessment in decision making. Recent climate change impact resulting high frequency of extreme events like heavy downpour, long dry spells, shifting length of growing period and temperature stress, are being studied in many parts of India (Aggarwal, 2008; Boomiraj et al., 2010). To mitigate climate change impact on soil and water resources, integrated watershed development interventions are desirable steps to reduce the negative impacts on productivity and livelihood security of rural poor (Joshi et al., 2008; Barron et al., 2009; Garg et al., 2012a).

Rainfed regions are highly vulnerable to degradation of natural resources, that hampered the socio economic development of the people in rainfed areas (Ninan and Lakshmikanthamma, 2001). The concept of watershed development programmes in India has evolved to ensure the effective use of natural resources such as land and water. The ultimate goal of economic growth and sustainable development of the agriculture sector of any country hinge on the effective use of these natural resources. Land, water, vegetation and human resources are the basic components of the watershed development programmes with the objective of boosting the agricultural productivity by adopting appropriate soil and moisture conservation technologies for socio-economic development of rural people (Joshi et al., 2004). Poverty reduction, improved livelihoods and enhanced bio-physical and socioeconomic status of the people will bring a holistic and sustainable development of the natural resources.
Watershed development projects in India has a long history of development however, very limited studies were conducted to quantify the impact of watershed interventions on biophysical aspects (Joshi et al., 2008; Glendenning et al., 2012). The impact of IWD interventions on ecosystem services is not well understood and this has under estimated the impact of watershed management programs in the country. There is also increasing concern about downstream water availability due to watershed interventions in upstream areas especially in dry lands regions (Bouma et al., 2011; Glendenning et al., 2012). The watershed development activities implemented in the rainfed areas have significantly influenced the various biophysical aspects such as soil and water conservation, soil fertility, positive impacts on cropping pattern, cropping intensity, production and productivity of crops (Barron et al., 2009; Vohland and Barry, 2009; Rockstrom et al., 2010; Glendenning and Vervoort, 2011; Wani et al., 2003, 2011a; Garg et al., 2012a, 2012b; Garg and Wani, 2012). Watershed interventions also helps in increased water table, perenniality of water in wells, water availability for cattle and other domestic uses ( Palanisami et al., 2009). However, few studies highlighted the negative impacts at the watershed and catchment scale (Batchelor et al., 2003; Sharma and Thakur, 2007; Bouma et al., 2011; Clemens and Demombynes, 2011; Bump et al., 2012). However, the impact study of larger reservoir catchments are scanty and reported very limited elshwhere. The present study aims to evaluate the impact of watershed interventions implemented under River Valley Project (RVP) in 149 micro watersheds of Mettur reservoir catchment of Tamil Nadu through random evaluation of 22 sample watersheds. The impact of comprehensive interventions in checking soil erosion, improving water availability, development of agro-forestry, 
sustainable management of natural resources, enhancement of agricultural productivity and socio-economic aspects of the farmers was studied. Assessment of effectiveness of watershed development programme, identification of major issues and lacunae in project implementation across the watersheds also has been studied.

\section{Study area}

The watershed programme was implemented to the total geographical area of 62,859 ha in 149 micro watersheds located in Mettur catchments. Among these only 22 watersheds covering an area of 22,700 ha from Dharmapuri, Salem and Krishnagiri districts were selected for the present impact evaluation study. The study area is semiarid with the normal annual rainfall of $1000 \mathrm{~mm}$ which is well distributed throughout the year. The mean annual air temperature of the study area is ranged from $26.9{ }^{\circ} \mathrm{C}$ to $28.0{ }^{\circ} \mathrm{C}$. An area of 17995 ha was occupied by alluvial and colluvium soils which contributes $88 \%$ of the area followed by 2376 ha (12\%) of red \& brown soil and black soils also could be seen in meager area. The slope of the lands in the project area varies from 0 to $30 \%$ and the maximum study area (51\%) falls below 3 to 8 percent slope group followed by 41 percent under the slope group of 8 to 25 percent and 7 percent in 0 to 3 percent slope and the rest of the area is under more than 25 percent slope group. In the study area agriculture contributes a major area $(60 \%)$ followed by forest $(19 \%)$, waste lands (13\%) and other land uses (8\%) (Fig1.).

Agriculture is the major occupation of the study watersheds and the crops like paddy, cholam, ragi, cumbu, coconut, groundnut, mango, vegetables and cotton are cultivated by the farmers. Details of twenty-two study watersheds are furnished in Table 1.

\section{Materials and Methods}

The present impact evaluation study was conducted through sample based before and after project evaluation approach, employing budgeting techniques. By employing stratified random sampling method 22 watersheds (SWS) were selected and the benchmark data collected by the PIA at the time of project planning were used for the study. After collecting benchmark data the impact indicators were enlisted (direct or surrogate indicators) to capture the status of provisionary, regulatory supportive and cultural services provided by the Mettur catchment system before and after the WSD program under RVP scheme. Provisionary services include the status of the level of production of food crops, horticultural produce, livestock products, regulatory services indicate rainwater conserved, regulate flow of water in the watershed system. Soil conserved, vegetation coverage, induced ecosystem, supportive service indicators - land smoothening, bunding, water quality, application of FYM etc. and cultural services includes infusion or diffusion of good land and water management practices, culture of maintaining and utilizing created assets on a sustained basis, social equity etc.

Study area was vast where project was implemented and not feasible to go for complete enumeration. Hence, multistage stratified sampling technique was adopted in selection of study watersheds (secondary sampling unit-SSU), farmers (primary sampling units-PSU) and structures for detailed surveys. SSU stratification was based on topographic sequence present in the project area namely watersheds located in upper reaches, middle reaches and lower reaches of the RVP area. The numbers of SSU from each topo-sequence was in proportion to the number of treated watersheds subject to minimum of two watersheds from each toposequence as well as the priority category. 
Selection of PSU from each SWS was again stratified based onto po-sequence in combination of socio economic variation present in the watershed and in proportion of number of households of different socioeconomic stratum in different topo-sequence subjected to minimum two PSU from each socio-economic stratum and maximum 10 PSUs from each topo-sequence from each watershed making 30 PSUs from each watershed. Transect walk with Watershed Development Team (WDT) members and farmers were conducted to verify the present status of structural design (assets) created during the project period. A ten per cent of each type of structure subject to minimum one structure from each SWS was selected for detailed investigation.

All the collected data were analyzed through budgeting techniques or appropriate statistics. The cash flow table was developed which were further aggregated along with other miscellaneous costs of the project to generate total cost and benefit stream of the project. Down-stream benefits (external benefits) in the command area through saving of pond age area by arresting silt within the catchments was also estimated in similar manner and aggregated to form stream of additional benefits of the project. Cash flow table was discounted at 10 per cent discount rate being a high priority activity of environmental security had priority lending rate. BenefitCost Ratio (BCR), Net Present Worth (NPW), Pay Back Period (PBP) and Internal Rate of Return (IRR) were estimated. Sensitivity analysis with respect to cost and benefits was done for $10 \%$ increase in cost, $20 \%$ decrease in benefits in isolation as well as both together. Higher rate of decrease in benefits was selected owing to high dependency of farming system on low rainfall situation in the area. Horticulture plantation (mango, coconut, tamarind, etc.) trees had more than 30 years technical life was taken as period of analysis under the study. Average situation of past 10years cost and benefit stream was taken for rest of the period to account future benefits and costs. The evaluation study was carried out during south-west and north-east monsoon period in each watershed to capture impact during both monsoon periods. Different types of works carried out in 22 selected RVP watersheds in Mettur catchments are:

\section{Soil and moisture conservation measures in agricultural lands\& wastelands}

1. Contour / field bund

2. Contour Staggered trenches

3. Vegetative Fencing

Drainage Line Treatment measures (DLTs)

1. Upper reaches - Loose boulders with vegetative support

2. Middle reaches - Loose boulders with vegetative support

3. Lower reaches - Gabion check dam with vegetative support

4. Silt detention tanks

\section{Water harvesting and recharge structures}

1. Water harvesting structures

2. Percolation ponds

\section{Production systems}

1. Horticulture plantation

2. Agro-forestry

3. Afforestation

Out of the different components, $25.61 \%$ of the budget was utilized for Soil and moisture conservation measures, $26.0 \%$ for drainage line treatments, $25.95 \%$ was utilized for creation of Water resources and management and for enhancing the production systems in the watersheds $21.15 \%$ budget amount was utilized. 


\section{Results and Discussion}

\section{Impacts of soil and water conservation measures}

Contour bunding / field bunding along with appropriate crop combination was proposed in the agricultural fields as an in-situ moisture conserve measure. Contour bunds were constructed in the agricultural fields with 5 to $12 \%$ slope. As all field boundaries are not along the contour in fragmented land holdings filed bunds were constructed. After the construction of bunds few farmers have adopted crop diversification due to enhanced insitu soil moisture conservation. In wastelands and the forestlands, contour staggered trenches have been taken up for harvesting runoff water and in-situ moisture conservation in sloping lands. The trees grown in these fields had better establishment and growth due to enhanced moisture content in the soil. The intensive contour and field bunding taken up in the agricultural fields has decreased the runoff and there by increased the water infiltration (Madhu et al., 2016). The bunds were strengthened by planting the locally available fodder grasses. It also supports to convert the bund area into productive land and sustainability of these structures. Dense plantation of the grasses works as vegetative filter strip in addition to fulfilling the need of fodder for the animals (Sudhishri et al., 2008). The bunds strengthened with locally available vegetative barriers considered as are inexpensive, feasible and durable bioengineering measure. The same technology has been adopted by the farmers of Kokriguda watershed of Orissa (Das et al., 2011). Vegetative fencing was made by growing the local plant species which was not liked by live stocks along the boundary to protect the agricultural and horticultural crops from domestic and wild animals. The overall performance of works was found to be satisfactory; however, few technical demerits were observed. In few locations, the trenches had not been excavated across the slope which results in improper water storage in the trenches.

\section{Impact of Drainage Line Treatment Measures}

Loose Boulder Check Dams (LBCD) are mostly constructed in first and second order streams of upper and middle reaches. The spacing of the check dams was decided by implementing agency such that the top of the check dam is of the same level of bottom of the previous check dam. In first order streams it about 48 per cent of these structures were found to be in good condition and functioning efficiently. Positive impact was gauged from the quantity of silt accumulated in the upstream side of the LBCDs. Similarly, LBCDs constructed in second order streams of middle reaches are found to be intact at 62 per cent. The LBCD constructed with locally available stones helps to stabilise the stream beds apart from reducing the velocity of water flow (Lenzi, 2002). After few years, these LBCDs act as water harvesting structures due to blocking of pores. Large number of the Gabion Check Dams (GCD) were constructed in middle reaches and 94 per cent of these structures found to be in good condition. Gabion Check Dams which were constructed on streams have stabilized the gullies in most of the places. Only one or two sites the gabions were constructed in meandering site. The drainage line treatments made their impacts in terms of arresting silts at the rate of about 12.6 cu.m. / year in one watershed and stabilized the gullies. Check dams in the watershed area also increase the soil fertility which enhances the growth of vegetation in the nearby region (Fullen and Booth, 2006).

In each watershed two to three silt detention tanks were constructed in series to trap the runoff water and silt. The capacity of these tanks varies from 3 to $4.5 \mathrm{ha}-\mathrm{cm}$ and cost is worked about to Rs.65,000/- to Rs. 80,000/-. 
The top width of the body wall is $0.6 \mathrm{~m}$ and the base width is $1.2 \mathrm{~m}$. The structures are intact at most of the places. Few places the impounding area was covered with Prosofis julifloara. Since it is also acting like a water harvesting structures, in the vicinity of the area it is noticed that water level in nearby tube wells has raised. Nearly 80 percent of the SDT are fully functional. Even the damaged structures had partly (upto 60\%) served their purpose as evident from slope reduction and silt deposited behind the structure. Apron provided as means to dissipate the runoff but at few places the aprons were damaged.

\section{Impact of water harvesting structures}

Majority of the WHS are functioning and were well maintained under the MNREGA scheme by desilting and clearing of Prosofis julifloara plants. Each water harvesting structures helps for recharging 2 to 3 open/tube wells which in turn enabled the farmers near the structures to irrigate the crops like tapioca, black gram and vegetables. Nearly 1-1.5 acres of agriculture land is being irrigated in both side of WHS in which additional area of 60-65 acres of land was brought under irrigation in each micro watershed. Surface water harvesting structures constructed to collect runoff water during high rainfall events were found effective.

A total of 751.5 ha-cm water storage capacity has been created in 22 selected watersheds of Mettur catchment. On an average about 50.1 ha-cm of additional water storage capacity in each watershed was created and it varied in the range of 40.06 to 56.10 ha-cm. It reveals that WHS has high relevance in the area. Kumari et al., (2014) found significant and quick impact of rain water harvesting structures on ground water recharge in Bundelkhand region. The harvested water helped mostly in ground water recharge besides directly used for livestock, domestic and non-domestic uses by the farmers. Rise in ground water table observed during the year 2014 in influence zone of water harvesting structures. On an average, rise in water table up to $0.89 \mathrm{~m}$, ranging from $0.10 \mathrm{~m}$ to as high as $0.65 \mathrm{~m}$, was observed in different watersheds. The difference in rise in water table was due to interventions taken in these watersheds, location of well or topo-sequence of study watersheds and other factors.

\section{Impact of artificial recharge structures}

Percolation ponds are considered as the important component of RVP watershed intervention for augmenting groundwater recharge in these regions. The storage capacity of these PPs varied between 20 ha$\mathrm{cm}$ and $50 \mathrm{ha}-\mathrm{cm}$. The out lets are made by stone pitching with 4-meter length and 2 to 3 $\mathrm{m}$ width in parabolic or trapezoidal shape. The additional water storage created helped in average of $5 \mathrm{~m}$ raise in water table of the open wells. This also contributed for additional irrigated area.

Percolation pond was the most suitable for recharge of groundwater and could increase the ground water level of $2.54 \mathrm{~m}$ after 2 years (Abraham and Mohan, 2019). One or two percolation ponds have filled thrice in a year. Due to continuous drought most of the PPs were not filled upto their full capacity during the evaluation period. Apparently in PPs, the cracking in the side walls and rilling on side slopes of bund was noticed.

The bunds around percolation ponds should be strengthened and supported by grasses, medicinal/aromatic plants, etc. Impacts in term of increase in water table, duration of water availability in wells with increase in well yield/recuperation under selected watersheds are presented and the details are given in table 2 . 
Table.1 Geographical description of the selected watersheds treated under River Valley Project in Mettur catchment

\begin{tabular}{|c|c|c|c|c|c|}
\hline Sl. No & Watershed code & Longitude & Latitude & Villages & $\begin{array}{l}\text { Total area } \\
\text { (ha) }\end{array}$ \\
\hline 1 & Athimutlu & $\begin{array}{l}77^{0} 46^{\prime} \mathrm{E} \\
77^{0} 47^{\prime} \mathrm{E}\end{array}$ & $\begin{array}{l}11^{0} 55^{\prime} \mathrm{N} \\
11^{0} 57^{\prime} \mathrm{N}\end{array}$ & Nagamarai & 514 \\
\hline 2 & Bettamugilalam & $\begin{array}{l}78^{0} 14^{\prime} \mathrm{E} \\
78^{0} 16^{\prime} \mathrm{E}\end{array}$ & $\begin{array}{l}11^{0} 59^{\prime} \mathrm{N} \\
12^{0} 03^{\prime} \mathrm{N}\end{array}$ & Badrahali,Manjarahalli,Harur & 851 \\
\hline 3 & Bevanatham & $\begin{array}{l}77^{0} 59^{\prime} \mathrm{E} \\
78^{0} 02^{\prime} \mathrm{E}\end{array}$ & $\begin{array}{l}12^{0} 09^{\prime} \mathrm{N} \\
12^{0} 11^{\prime} \mathrm{N}\end{array}$ & $\begin{array}{l}\text { Anjahatty, Sigaralahully, } \\
\text { Tittoppnahally, Vattuvanahally }\end{array}$ & 1086 \\
\hline 4 & Billalam & $\begin{array}{l}77^{0} 38^{\prime} \mathrm{E} \\
77^{0} 40^{\prime} \mathrm{E}\end{array}$ & $\begin{array}{l}12^{0} 18^{\prime} \mathrm{N} \\
12^{0} 20^{\prime} \mathrm{N}\end{array}$ & Thegatti, Kottaiyur & 964 \\
\hline 5 & ChithandaPuram & $\begin{array}{l}78^{0} 14^{\prime} \mathrm{E} \\
78^{0} 16^{\prime} \mathrm{E}\end{array}$ & $\begin{array}{l}11^{0} 59^{\prime} \mathrm{N} \\
12^{0} 03^{\prime} \mathrm{N}\end{array}$ & Athinauttulu,Chickkadhoranabeta & 1218 \\
\hline 6 & Gummanur & $\begin{array}{l}78^{0} 00^{\prime} \mathrm{E} \\
78^{0} 00^{\prime} \mathrm{E}\end{array}$ & $\begin{array}{l}12^{0} 02^{\prime} \mathrm{N} \\
12^{0} 06^{\prime} \mathrm{N}\end{array}$ & $\begin{array}{l}\text { Arakasanahalli, Nekkunthy, } \\
\text { Nagerkoodal, Kumbalapadai }\end{array}$ & 1412 \\
\hline 7 & Karandapalli & $\begin{array}{l}78^{0} 14^{\prime} \mathrm{E} \\
78^{0} 16^{\prime} \mathrm{E}\end{array}$ & $\begin{array}{l}11^{0} 59^{\prime} \mathrm{N} \\
12^{0} 03^{\prime} \mathrm{N}\end{array}$ & Thonnakuttahalli & 1602 \\
\hline 8 & Kukkuttamaradahalli & $\begin{array}{l}77^{0} 43^{\prime} \mathrm{E} \\
77^{0} 50^{\prime} \mathrm{E}\end{array}$ & $\begin{array}{l}12^{0} 20^{\prime} \mathrm{N} \\
12^{0} 24^{\prime} \mathrm{N}\end{array}$ & Anjetti & 900 \\
\hline 9 & Nagamarai & $\begin{array}{l}78^{0} 52^{\prime} \mathrm{E} \\
78^{0} 57^{\prime} \mathrm{E}\end{array}$ & $\begin{array}{l}12^{0} 28^{\prime} \mathrm{N} \\
12^{0} 32^{\prime} \mathrm{N}\end{array}$ & Rathnagiri, Bevunatham & 984 \\
\hline 10 & Natrampalayam & $\begin{array}{l}77^{0} 45^{\prime} \mathrm{E} \\
78^{0} 50^{\prime} \mathrm{E}\end{array}$ & $\begin{array}{l}12^{0} 49^{\prime} \mathrm{N} \\
12^{0} 55^{\prime} \mathrm{N}\end{array}$ & $\begin{array}{l}\text { Ramakondahalli, } \\
\text { Nagamarai }\end{array}$ & 744 \\
\hline 11 & Pudukadu & $\begin{array}{l}77^{0} 58^{\prime} \mathrm{E} \\
78^{0} 08^{\prime} \mathrm{E}\end{array}$ & $\begin{array}{l}12^{0} 24^{\prime} \mathrm{N} \\
12^{0} 29^{\prime} \mathrm{N}\end{array}$ & $\begin{array}{l}\text { Chikkadorannabettam, Chudanur, } \\
\text { Gummanur }\end{array}$ & 727 \\
\hline 12 & PuduPatti & $\begin{array}{l}77^{0} 56^{\prime} \mathrm{E} \\
77^{0} 59^{\prime} \mathrm{E}\end{array}$ & $\begin{array}{l}12^{0} 03^{\prime} \mathrm{N} \\
12^{0} 05^{\prime} \mathrm{N}\end{array}$ & $\begin{array}{l}\text { Eraappayanahalli, Echchanahalli, } \\
\text { Nekkundi, Pudupatti, Kadamadai }\end{array}$ & 1418 \\
\hline 13 & Puvankadu & $\begin{array}{l}78^{0} 50^{\prime} \mathrm{E} \\
78^{0} 00^{\prime} \mathrm{E}\end{array}$ & $\begin{array}{l}12^{0} 00^{\prime} \mathrm{N} \\
12^{0} 10^{\prime} \mathrm{N}\end{array}$ & $\begin{array}{l}\text { Senganur, Sathyanathapuram, } \\
\text { Kukuttamaradhalli, Kadamadai }\end{array}$ & 1501 \\
\hline 14 & Ramakondahalli & $\begin{array}{l}77^{0} 44^{\prime} \mathrm{E} \\
77^{0} 47^{\prime} \mathrm{E}\end{array}$ & $\begin{array}{l}12^{0} 16^{\prime} \mathrm{N} \\
12^{0} 18^{\prime} \mathrm{N}\end{array}$ & Gerahatti, Sesurajapuram & 908 \\
\hline 15 & Ramapuram & $\begin{array}{l}77^{\circ} 43^{\prime} \mathrm{E} \\
77^{0} 45^{\prime} \mathrm{E}\end{array}$ & $\begin{array}{l}12^{0} 26^{\prime} \mathrm{N} \\
12^{0} 31^{\prime} \mathrm{N}\end{array}$ & $\begin{array}{l}\text { Palayankotta, Anthevanapalli, } \\
\text { Malligarjunadurgam, Kottur, } \\
\text { Thavarakarai, Karandapalli, }\end{array}$ & 1150 \\
\hline 16 & Salivaram & $\begin{array}{l}78^{0} 03^{\prime} \mathrm{E} \\
78^{0} 04^{\prime} \mathrm{E}\end{array}$ & $\begin{array}{l}11^{0} 58^{\prime} \mathrm{N} \\
12^{0} 15^{\prime} \mathrm{N}\end{array}$ & $\begin{array}{l}\text { Manidahalli, Dokkubothanahalli, } \\
\text { Bolonahalli }\end{array}$ & 1328 \\
\hline 17 & Sathirapatti & $\begin{array}{l}78^{0} 14^{\prime} \mathrm{E} \\
78^{0} 16^{\prime} \mathrm{E}\end{array}$ & $\begin{array}{l}11^{0} 59^{\prime} \mathrm{N} \\
12^{0} 03^{\prime} \mathrm{N}\end{array}$ & Dharmapuri, Morappur, Pappiradypatti & 1998 \\
\hline 18 & Sigaralahalli & $\begin{array}{l}78^{0} 14^{\prime} \mathrm{E} \\
78^{0} 16^{\prime} \mathrm{E}\end{array}$ & $\begin{array}{l}11^{0} 59^{\prime} \mathrm{N} \\
12^{0} 03^{\prime} \mathrm{N}\end{array}$ & Bevanathan & 1622 \\
\hline 19 & Sorankanpudur & $\begin{array}{l}77^{0} 46^{\prime} \mathrm{E} \\
77^{0} 51^{\prime} \mathrm{E}\end{array}$ & $\begin{array}{l}12^{0} 32^{\prime} \mathrm{N} \\
12^{0} 28^{\prime} \mathrm{N}\end{array}$ & $\begin{array}{l}\text { Naganoor, Dekanikottai, } \\
\text { Santhanappalli, Arasakuppam, } \\
\text { Bevanatham, Ulimangalam }\end{array}$ & 2008 \\
\hline 20 & Sorrakapatti & $\begin{array}{l}77^{0} 56^{\prime} \mathrm{E} \\
77^{0} 59^{\prime} \mathrm{E}\end{array}$ & $\begin{array}{l}12^{0} 15^{\prime} \mathrm{N} \\
12^{0} 17^{\prime} \mathrm{N}\end{array}$ & Bevuhalli, Vattuvanahalli & 1252 \\
\hline 21 & Theggaty & $\begin{array}{l}78^{0} 14^{\prime} \mathrm{E} \\
78^{0} 16^{\prime} \mathrm{E}\end{array}$ & $\begin{array}{l}11^{0} 59^{\prime} \mathrm{N} \\
12^{0} 03^{\prime} \mathrm{N}\end{array}$ & Kolalti,Salivaram & 587 \\
\hline 22 & Vattuvanahalli & $\begin{array}{l}77^{0} 45^{\prime} \mathrm{E} \\
77^{0} 51^{\prime} \mathrm{E}\end{array}$ & $\begin{array}{l}12^{0} 24^{\prime} \mathrm{N} \\
12^{0} 27^{\prime} \mathrm{N}\end{array}$ & Erudukottai,Bilalum,Kolam & 1041 \\
\hline
\end{tabular}


Table.2 Number of open wells and tube wells in different SWS during before and after project

\begin{tabular}{|c|c|c|c|c|c|c|c|c|}
\hline \multirow[t]{2}{*}{ Name of the watershed } & \multicolumn{2}{|c|}{ Open well (Nos) } & \multicolumn{2}{|c|}{ Tube well (Nos) } & \multicolumn{4}{|c|}{ Open well (Water level in m) } \\
\hline & Before & After & Before & After & Before & After & Increase & Increase $(\%)$ \\
\hline Athimutlu & 12 & 7 & - & 1 & 1.33 & 1.38 & 0.05 & 3.76 \\
\hline Bettamugilalam & 1 & 2 & 1 & 1 & 2.00 & 2.35 & 0.35 & 17.50 \\
\hline Bevanatham & 5 & 4 & - & - & 2.00 & 2.18 & 0.18 & 9.00 \\
\hline Billalam & 4 & 4 & 2 & 3 & 5.50 & 6.00 & 0.50 & 9.09 \\
\hline ChithandaPuram & 11 & 9 & - & 1 & 3.55 & 3.80 & 0.25 & 7.04 \\
\hline Gummanur & 9 & 8 & 2 & 2 & 3.22 & 3.48 & 0.26 & 8.07 \\
\hline Karandapalli & 6 & 6 & - & 5 & 3.33 & 3.43 & 0.10 & 3.00 \\
\hline Kukkuttamaradahalli & 7 & 5 & - & 5 & 3.71 & 3.79 & 0.08 & 2.16 \\
\hline Nagamarai & 5 & 3 & - & - & 2.25 & 2.36 & 0.11 & 4.89 \\
\hline Natrampalayam & 1 & 1 & 1 & 1 & 2.00 & 1.98 & -0.02 & -1.00 \\
\hline Pudukadu & 18 & 9 & - & - & 2.24 & 2.38 & 0.14 & 6.25 \\
\hline PuduPatti & 14 & 6 & - & 1 & 3.22 & 3.29 & 0.07 & 2.17 \\
\hline Puvankadu & 3 & 5 & 3 & 3 & 1.00 & 0.98 & -0.02 & -2.00 \\
\hline Ramakondahalli & 4 & 4 & - & 2 & 3.50 & 3.62 & 0.12 & 3.43 \\
\hline Ramapuram & 3 & 4 & 1 & 1 & 5.00 & 5.50 & 0.50 & 10.00 \\
\hline Salivaram & 8 & 9 & 4 & 5 & 7.00 & 7.89 & 0.89 & 12.71 \\
\hline Sathirapatti & 18 & 13 & - & - & 3.39 & 3.65 & 0.26 & 7.67 \\
\hline Sigaralahalli & 11 & 10 & 4 & 5 & 2.82 & 2.79 & -0.03 & -1.06 \\
\hline Sorankanpudur & 12 & 13 & 3 & 3 & 3.78 & 3.80 & 0.02 & 0.53 \\
\hline Sorrakapatti & 10 & 12 & 3 & 3 & 4.70 & 4.58 & -0.12 & -2.55 \\
\hline Theggaty & 2 & 2 & - & 2 & 4.50 & 4.69 & 0.19 & 4.22 \\
\hline Vattuvanahalli & 10 & 5 & - & 2 & 4.67 & 5.10 & 0.43 & 9.21 \\
\hline Total/ Average & 174 & 141 & 24 & 46 & 3.40 & 3.59 & 0.20 & 5.19 \\
\hline
\end{tabular}

Fig.1 Area under different land uses in study watersheds

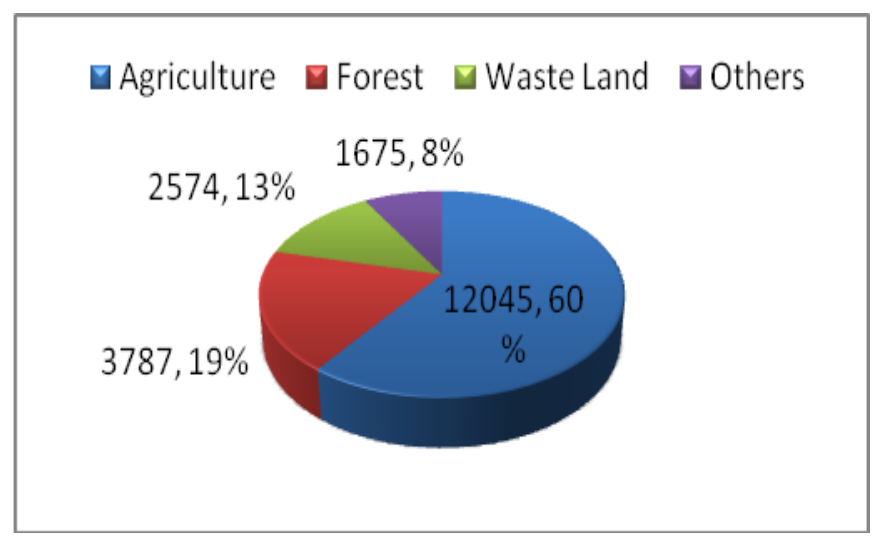


Table.3 Impact of RVP watershed project in recuperation rate in Mettur catchments

\begin{tabular}{|c|l|c|c|c|c|}
\hline \multirow{2}{*}{ SI.No. Watershed } & \multicolumn{3}{|c|}{ Recuperation rate $\left.\mathbf{( m}^{\mathbf{3}} \mathbf{h r}\right)$} & Increase \\
\cline { 3 - 5 } & & Before & After & Increase & $\mathbf{( \% )}$ \\
\hline $\mathbf{1}$ & Athimutlu & 0.89 & 0.90 & 0.01 & 1.12 \\
\hline $\mathbf{2}$ & Bettamugilalam & 1.16 & 1.18 & 0.02 & 1.72 \\
\hline $\mathbf{3}$ & Bevanatham & 1.19 & 1.22 & 0.03 & 2.52 \\
\hline $\mathbf{4}$ & Billalam & 2.11 & 2.12 & 0.01 & 0.47 \\
\hline $\mathbf{5}$ & ChithandaPuram & 1.70 & 1.73 & 0.03 & 1.76 \\
\hline $\mathbf{6}$ & Gummanur & 1.49 & 1.52 & 0.03 & 2.01 \\
\hline $\mathbf{7}$ & Karandapalli & 1.55 & 1.55 & 0.00 & 0.00 \\
\hline $\mathbf{8}$ & Kukkuttamaradahalli & 1.80 & 1.83 & 0.03 & 1.67 \\
\hline $\mathbf{9}$ & Nagamarai & 1.15 & 1.16 & 0.01 & 0.87 \\
\hline $\mathbf{1 0}$ & Natrampalayam & 1.18 & 1.20 & 0.02 & 1.27 \\
\hline $\mathbf{1 1}$ & Pudukadu & 1.15 & 1.16 & 0.01 & 0.87 \\
\hline $\mathbf{1 2}$ & Pudupatti & 1.49 & 1.52 & 0.03 & 2.01 \\
\hline $\mathbf{1 3}$ & Puvankadu & 0.68 & 0.69 & 0.01 & 1.47 \\
\hline $\mathbf{1 4}$ & Ramakondahalli & 1.65 & 1.69 & 0.04 & 2.42 \\
\hline $\mathbf{1 5}$ & Ramapuram & 2.10 & 2.15 & 0.05 & 2.38 \\
\hline $\mathbf{6}$ & Salivaram & 2.15 & 2.18 & 0.03 & 1.40 \\
\hline $\mathbf{1 7}$ & Sathirapatti & 1.58 & 1.60 & 0.02 & 1.27 \\
\hline $\mathbf{1 8}$ & Sigaralahalli & 1.38 & 1.39 & 0.01 & 0.72 \\
\hline $\mathbf{1 9}$ & Sorankanpudur & 1.80 & 1.80 & 0.00 & 0.00 \\
\hline $\mathbf{2 0}$ & Sorrakapatti & 2.10 & 2.11 & 0.01 & 0.48 \\
\hline $\mathbf{2 1}$ & Theggaty & 1.95 & 1.98 & 0.03 & 1.54 \\
\hline $\mathbf{2 2}$ & Vattuvanahalli & 2.00 & 2.03 & 0.03 & 1.50 \\
\hline & Average & 1.56 & 1.58 & 0.02 & 1.34 \\
\hline
\end{tabular}

Fig.2 Rainfall, runoff and soil loss in 4B3B3r2 watershed in Mettur catchment

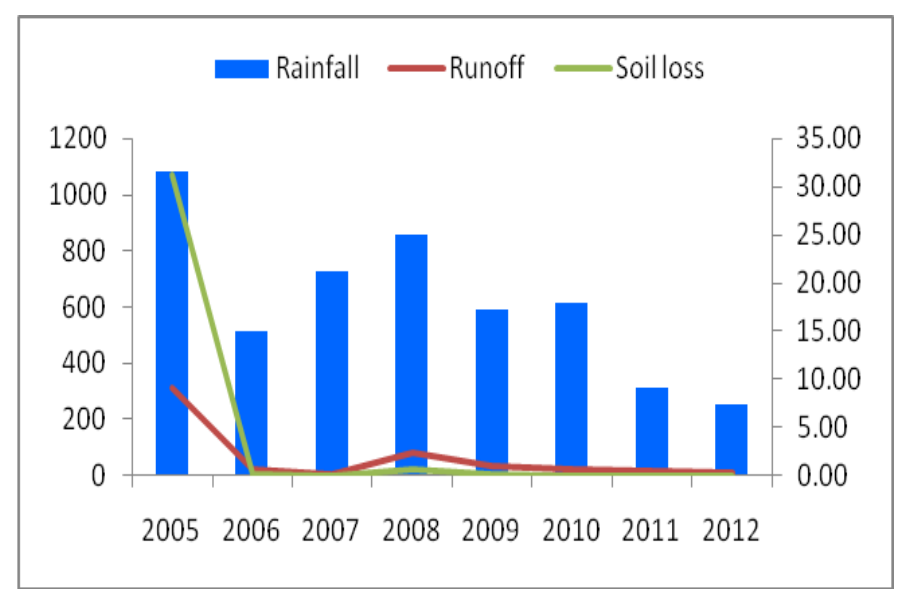


Table.4 Estimated quantity of silt trapped in the WHS, SDT and FPs in selected watersheds at Mettur catchment

\begin{tabular}{|c|c|c|c|c|c|c|c|}
\hline \multirow[t]{2}{*}{ Sl.No. } & \multirow[t]{2}{*}{ Watershed } & \multicolumn{2}{|c|}{$\begin{array}{c}\text { Water Harvesting } \\
\text { structures }\end{array}$} & \multicolumn{2}{|c|}{ Farm Pond } & \multicolumn{2}{|c|}{ Silt Detention Tank } \\
\hline & & Nos. & $\begin{array}{c}\text { Silt } \\
\text { deposition } \\
\text { (cum) }\end{array}$ & Nos. & $\begin{array}{c}\text { Silt } \\
\text { deposition } \\
\text { (cum) }\end{array}$ & Nos. & $\begin{array}{c}\text { Silt deposition } \\
\text { (cum) }\end{array}$ \\
\hline 1 & Athimutlu & 3 & 165 & 2 & 18 & 5 & 144 \\
\hline 2 & Bettamugilalam & 4 & 300 & 2 & 50 & 4 & 192 \\
\hline 3 & Bevanatham & 3 & 180 & 0 & 0 & 6 & 202 \\
\hline 4 & Billalam & 4 & 260 & 4 & 36 & 33 & 1267 \\
\hline 5 & ChithandaPuram & 2 & 110 & 4 & 80 & 11 & 317 \\
\hline 6 & Gummanur & 1 & 60 & 1 & 12 & 3 & 101 \\
\hline 7 & Karandapalli & 4 & 220 & 4 & 36 & 4 & 115 \\
\hline 8 & Kukkuttamaradahalli & 6 & 315 & 8 & 154 & 10 & 264 \\
\hline 9 & Nagamarai & 3 & 165 & 1 & 9 & 3 & 86 \\
\hline 10 & Natrampalayam & 1 & 80 & 1 & 12 & 0 & 0 \\
\hline 11 & Pudukadu & 2 & 180 & 4 & 48 & 7 & 437 \\
\hline 12 & PuduPatti & 1 & 125 & 0 & 0 & 1 & 96 \\
\hline 13 & Puvankadu & 1 & 115 & 0 & 0 & 2 & 173 \\
\hline 14 & Ramakondahalli & 2 & 156 & 0 & 0 & 2 & 102 \\
\hline 15 & Ramapuram & 5 & 475 & 1 & 7 & 16 & 1075 \\
\hline 16 & Salivaram & 2 & 270 & 0 & 0 & 3 & 317 \\
\hline 17 & Sathirapatti & 2 & 156 & 0 & 0 & 4 & 204 \\
\hline 18 & Sigaralahalli & 2 & 350 & 0 & 0 & 4 & 576 \\
\hline 19 & Sorankanpudur & 2 & 128 & 1 & 7 & 7 & 262 \\
\hline 20 & Sorrakapatti & 3 & 264 & 0 & 0 & 5 & 302 \\
\hline 21 & Theggaty & 7 & 844 & 1 & 19 & 6 & 550 \\
\hline \multirow[t]{2}{*}{22} & Vattuvanahalli & 4 & 336 & 1 & 12 & 2 & 113 \\
\hline & Total & 64 & 5254 & 35 & 499 & 138 & 6895 \\
\hline
\end{tabular}

Fig.3 Rainfall, runoff and soil loss in 4B3B1h1 watershed in Mettur catchment

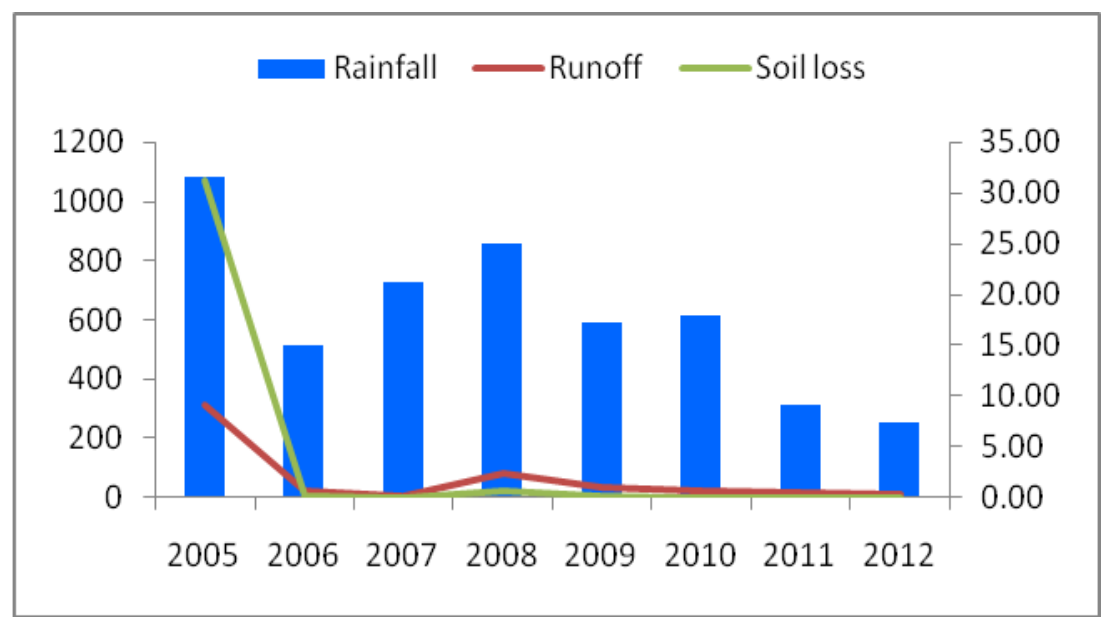


Table.5 Storage capacity created in the selected watersheds in Mettur catchments

\begin{tabular}{|c|c|c|c|c|c|c|c|}
\hline \multirow[t]{2}{*}{ Sl.No. } & \multirow[t]{2}{*}{ Watershed } & \multicolumn{2}{|c|}{$\begin{array}{c}\text { Water Harvesting } \\
\text { structures }\end{array}$} & \multicolumn{2}{|c|}{ Farm Pond } & \multicolumn{2}{|c|}{ Silt Detention Tank } \\
\hline & & Nos. & $\begin{array}{c}\text { Storage } \\
\text { created (cum) }\end{array}$ & Nos. & $\begin{array}{c}\text { Storage } \\
\text { created } \\
\text { (cum) }\end{array}$ & Nos. & $\begin{array}{c}\text { Storage } \\
\text { created (cum) }\end{array}$ \\
\hline 1 & Athimutlu & 3 & 3600 & 2 & 540 & 5 & 8250 \\
\hline 2 & Bettamugilalam & 4 & 4290 & 2 & 540 & 4 & 7128 \\
\hline 3 & Bevanatham & 3 & 8100 & - & - & 6 & 5940 \\
\hline 4 & Billalam & 4 & 7920 & 4 & 941 & 33 & 21344 \\
\hline 5 & ChithandaPuram & 2 & 4200 & 4 & 1080 & 11 & 8276 \\
\hline 6 & Gummanur & 1 & 2009 & 1 & 347 & 3 & 3366 \\
\hline 7 & Karandapalli & 4 & 7200 & 4 & 1920 & 4 & 4171 \\
\hline 8 & Kukkuttamaradahalli & 6 & 12636 & 8 & 3840 & 10 & 6732 \\
\hline 9 & Nagamarai & 3 & 6750 & 1 & 750 & 3 & 1762 \\
\hline 10 & Natrampalayam & 1 & 1170 & 1 & 750 & - & - \\
\hline 11 & Pudukadu & 2 & 2937 & 4 & 1920 & 7 & 2218 \\
\hline 12 & PuduPatti & 1 & 1710 & - & - & 1 & 990 \\
\hline 13 & Puvankadu & 1 & 792 & - & - & 2 & 1399 \\
\hline 14 & Ramakondahalli & 2 & 4500 & - & - & 2 & 1584 \\
\hline 15 & Ramapuram & 5 & 8745 & 1 & 235 & 16 & 11616 \\
\hline 16 & Salivaram & 2 & 3600 & - & - & 3 & 2772 \\
\hline 17 & Sathirapatti & 2 & 3300 & - & - & 4 & 4039 \\
\hline 18 & Sigaralahalli & 2 & 4620 & - & - & 4 & 2904 \\
\hline 19 & Sorankanpudur & 2 & 4590 & 1 & 270 & 7 & 6607 \\
\hline 20 & Sorrakapatti & 3 & 4950 & - & - & 5 & 3696 \\
\hline 21 & Theggaty & 7 & 15015 & 1 & 347 & 6 & 3762 \\
\hline \multirow[t]{2}{*}{22} & Vattuvanahalli & 4 & 6720 & 1 & 270 & 2 & 634 \\
\hline & Total & 64 & 119354 & 35 & 13750 & 138 & 109190 \\
\hline
\end{tabular}

Table.6 Disparity between irrigated and rain fed area in RVP watersheds of Mettur catchment during pre and post project period

\begin{tabular}{|c|l|c|c|c|c|c|c|}
\hline SI.No. & Watershed code & \multicolumn{3}{|c|}{ Irrigated area (ha) } & \multicolumn{3}{c|}{ Rainfed area (ha) } \\
\cline { 3 - 8 } & & $\begin{array}{c}\text { Before } \\
\text { Project }\end{array}$ & $\begin{array}{c}\text { After } \\
\text { Project }\end{array}$ & $\begin{array}{c}\text { Percent } \\
\text { change }\end{array}$ & $\begin{array}{c}\text { Before } \\
\text { Project }\end{array}$ & $\begin{array}{c}\text { After } \\
\text { Project }\end{array}$ & $\begin{array}{c}\text { Percent } \\
\text { change }\end{array}$ \\
\hline 1. & Athimutlu & 9.0 & 13.6 & 50.4 & 19.8 & 14.7 & 25.7 \\
\hline 2. & Bettamugilalam & 10.0 & 14.0 & 40.3 & 14.7 & 10.3 & 30.3 \\
\hline 3. & Bevanatham & 11.5 & 17.7 & 54.3 & 21.6 & 15.3 & 29.0 \\
\hline 4. & Billalam & 2.0 & 8.5 & 320.4 & 31.8 & 25.4 & 20.1 \\
\hline $\mathbf{5 .}$ & ChithandaPuram & 4.0 & 6.4 & 59.4 & 26.7 & 24.3 & 9.1 \\
\hline 6. & Gummanur & 2.2 & 4.0 & 82.4 & 31.3 & 29.5 & 5.8 \\
\hline 7. & Karandapalli & 13.1 & 16.9 & 29.5 & 15.7 & 11.9 & 24.5 \\
\hline
\end{tabular}




\begin{tabular}{|c|l|c|c|c|c|c|c|}
\hline 8. & Kukkuttamaradahalli & 5.6 & 8.5 & 50.2 & 45.9 & 43.0 & 6.3 \\
\hline 9. & Nagamarai & 5.4 & 10.7 & 96.3 & 19.4 & 15.6 & 19.8 \\
\hline 10. & Natrampalayam & 11.0 & 15.9 & 44.0 & 20.2 & 15.3 & 24.0 \\
\hline 11. & Pudukadu & 13.3 & 21.1 & 58.9 & 24.9 & 16.4 & 34.2 \\
\hline 12. & PuduPatti & 7.3 & 12.1 & 66.6 & 29.5 & 24.7 & 16.5 \\
\hline 13. & Puvankadu & 28.0 & 30.8 & 10.1 & 17.6 & 16.4 & 6.9 \\
\hline 14. & Ramakondahalli & 13.3 & 20.2 & 52.1 & 55.4 & 38.0 & 31.5 \\
\hline 15. & Ramapuram & 17.3 & 18.3 & 6.0 & 17.6 & 15.1 & 14.3 \\
\hline 16. & Salivaram & 2.8 & 3.4 & 21.4 & 20.8 & 19.8 & 4.8 \\
\hline 17. & Sathirapatti & 11.0 & 13.3 & 21.3 & 29.5 & 25.1 & 15.1 \\
\hline 18. & Sigaralahalli & 7.9 & 11.9 & 51.3 & 22.6 & 18.6 & 17.9 \\
\hline 19. & Sorankanpudur & 14.1 & 14.1 & 0.0 & 22.0 & 22.0 & 0.0 \\
\hline 20. & Sorrakapatti & 19.4 & 19.9 & 2.6 & 8.4 & 7.0 & 16.8 \\
\hline 21. & Theggaty & 35.3 & 40.3 & 14.1 & 34.8 & 30.1 & 13.4 \\
\hline 22. & Vattuvanahalli & 9.5 & 13.5 & 42.6 & 16.0 & 11.9 & 25.3 \\
\hline
\end{tabular}

Table.7 Benefit cost analysis of Mettur watersheds at $10 \%$ discount rate

\begin{tabular}{|c|c|c|}
\hline \multirow{2}{*}{ Evaluation Criteria } & \multicolumn{2}{|c|}{ Situation } \\
\cline { 2 - 3 } & Tangible benefits only & $\begin{array}{c}\text { Tangible + Nutrient } \\
\text { saved }\end{array}$ \\
\hline NPV (Lakh Rs.) & 77064 & 94368 \\
\hline BCR & $1.68: 1$ & $1.75: 1$ \\
\hline PBP(Years) & 7 & 6 \\
\hline IRR (\%) & 55 & 68 \\
\hline
\end{tabular}

\section{Impact on Ground Water Resources}

\section{Duration of Water Availability in Wells}

The watershed impact data of 187 wells in Mettur watersheds was studied. The data indicates that 50 per cent of the sample wells had water for more than 9 months during the evaluation period as compared to 38 per cent before the project period. In general, the impact was marginal which was attributed to low rainfall with poor distribution during the

\section{Well recuperation rate}

The results of recuperation data collected for different watersheds are presented in table 3. project period. However, study clearly reveals the WSM activities under RVP scheme in Mettur watersheds had impacted positively in longevity of water availability in wells. Another very positive aspect of the project was no drying or reduction in water availability in the wells situated at upper location/reaches of the SWS of the study area rather it increases there too. However, the level of rise or longevity of water in wells is less than wells located in lower reaches.

Recuperation rate after WSM project increased upto 2.52 per cent in different SWS. The maximum recuperation rate was observed in Bevanatham watershed and there is no change in Karandapalli and Sorankanpudur 
watershed. The recuperation rate was influenced primarily attributed to distance of wells from the location of water harvesting structure and quantum of water available in the structure besides quantum of rainfall in the watershed.

\section{Impact on Surface Runoff}

Gauging stations were installed in few selected locations to monitor runoff and soil loss from the watersheds under treatment. Surface runoff was found to be 4.5 to 5.6 per cent of the rainfall for selected rainfall events. Based on silt deposited behind selected check dams/ponds, soil loss was estimated to vary in the range of 2.3 to $3.51 \mathrm{t} \mathrm{ha}^{-1} \mathrm{yr}^{-1}$, which is very well within the permissible limit. The observed values are given in figure 2 and 3 .

The peak rate of runoff has been reduced considerably. This shows the clear positive impact of the watershed programme on regulatory services. This suggests that most of the rain was conserved and runoff was stored within the watershed to help augment groundwater recharge.

In-situ as well as ex-situ rain water conservation measures implemented in SWS helped to retain detached soil due to rain drop impact with in various SWC structures constructed in the watershed. The silt deposited behind ex-situ conservation measures namely WHS, PP, STDs of sample structures estimated from SWS is presented in Table 4.

\section{Impact on Increase in Storage Capacity}

A total of 2422 ha-cm additional surface water storage capacity has been created through water harvesting structures in the 22 selected watersheds. The additional water storage capacity has helped in improving groundwater recharge and water availability for cattle and other non-domestic uses in the watershed. Additional storage capacity created together with the status of irrigated area and irrigated crops are presented in table 5.

\section{Disparity between Irrigated and Rainfed Area in RVP Watersheds}

Detailed survey conducted for few farmers in these watersheds whose cultivable land exist close to WHS/SDT is presented in table 6. It could be observed that slight increase in irrigated area around the water harvesting structures occurred due to increase in ground water table, well yield/recuperation and duration of water availability in the wells. The irrigated area has been increased by 50 to 320 $\%$ in the Mettur catchment after the implementation of the project. Among various watersheds in the catchment, the highest increase in area under irrigation $(320 \%)$ was observed in Puvankadu watershed which was followed by Vattuvanahalli watershed (96.3\%) and Ramakondahalli watershed $(82.4 \%)$. The area under rainfed has decreased by maximum of $34 \%$. Madhu et al (2016) found an additional area of 24.2 ha could be cultivated with paddy and vegetables under irrigation for due to watershed interventions.

\section{Impact on production systems}

Afforestation with silver oak, tamarind, teak etc., was done in common lands and also on the bunds of agricultural land in addition to supply of horticultural plants such as Mango, Sapota, Amla, Lemon and Guava. Survival of plants was satisfactory in-home stead due to better care taken up by the beneficiaries. The farmers with irrigation facility have planted coconut in their fields. Under agro-forestry and road side plantation, tree seedlings like silver oak (Grevelia robusta) were planted in the watersheds area. This activity was taken up in all the watersheds with the total cost of 
Rs.1.38 lakhs. The performance of seedlings would have been improved through proper care and maintenance. The fruit trees, mostly planted in homesteads, are expected to yield fruits in another 2-3 years which can cater to be domestic needs and improvement of nutrition of the family members. The trees planted on boundaries and on-stream banks also will improve the greenery and in turn help in conservation. Under afforestation works, the forest tree species mainly Acacia planiforus, Pungam, Acacia nilotica, Acacia lucafolia, Cassia siamia, Kudavel, Velvel, Klaklushave had been planted in the reserve forest area of Veppanahalli watershed. Trenches taken for in-situ moisture conservation helped for the survival of the plants in spite of monsoon failure during the year 2011 \& 2012.

\section{Impact on Land Use and Crop Productivity}

Watershed programmes have influential effect on land use, crop yields, cropping intensity, fertilizer use, etc., as a result of improved insitu moisture conservation, increased water availability, improved farming practices and diversified land use systems. Watershed interventions in Mettur catchment have increased the area under cultivation to 843 ha from 585 ha. Area under pasture has been reduced by $43 \%$ due to diversion of these lands to other land uses. Area under field crops, vegetable and orchard has increased by $21 \%, 91 \%$ and $138 \%$ respectively. The important land use shift after the implementation of the project is that the area under fodder has been increased from 2 ha to 21.8 ha. Among different catchments in the watershed, there was a $400 \%$ increase in field crop cultivation in Natrampalayam watershed. Unlike field crops, whose area was in either increasing or decreasing trend in different watersheds, the area under vegetable cultivation has increased in all the watersheds in the catchment due to water availability.

\section{Benefit cost analysis}

$\mathrm{BCA}$ of the project was done by considering 25 years project life at $10 \%$ discount rate. The net present value of the project is about Rs. 770 crores without considering intangible benefits. The BCR (1.68:1) and IRR (50\%) amply indicated the economic soundness of the project (Table 7). The whole investment made in the project can be recovered within seven years. The values of the economic viability of the project improved by inclusion the monetary value of the nutrient saved by way of reduction in soil erosion. The value of NPV was more than Rs. 943 crores with 1.75:1 B:C ratio and $68 \%$ IRR. All the criteria of economic evaluation indicate that such projects are highly economically sound to be taken on priority for sustainable agricultural growth (Palanisami and Suresh Kumar, 2009).

In conclusions the study reveals that the impact on surface runoff reduction was found to be 4.5 to 5.6 per cent and soil loss was estimated to vary in the range of 2.3 to $3.51 \mathrm{t}$ $\mathrm{ha}^{-1} \mathrm{yr}^{-1}$. Additional surface water storage of 2422 ha-cm has been created through water harvesting structures in the 22 selected watersheds. On an average, rise in water table up to $0.89 \mathrm{~m}$, ranging from $0.10 \mathrm{~m}$ to as high as $0.65 \mathrm{~m}$, was observed in different watersheds. The net present value of the project was more than Rs. 943 crore with $1.75: 1 \mathrm{BCR}$ and $68 \%$ IRR. All the criteria of economic evaluation indicate that such projects are highly economically and be taken up on priority for sustainable agricultural growth in the region. The overall impact in realizing the objectives of the project at Mettur catchments was very good. The project was found to be technically feasible and economically viable. To realize long term impact of the watershed activities and 
document project sustainability, it is suggested that implementing agency, should monitor the watersheds in terms of socioeconomic and bio physical changes in long term period, say at least 10 years after withdrawal of project. Though the project has made positive impact in the project area, it lacks required convergence and linkages with the line departments such as Agriculture, Horticulture, Rural Development, Forestry etc. At least, at this phasing out stage, project must develop strong linkages with these departments to integrate their developmental schemes with this project and actively involve them as partners for better convergence and ensure sustainability after its withdrawal.

\section{Acknowledgement}

Authors are highly grateful to the Agricultural Engineering Department, Government of Tamil Nadu, Chennai for sponsoring this impact evaluation study.

\section{References}

Abraham, M.K. and Mohan, S. 2019. Effectiveness of check dam and percolation pond with percolation wells for artificial groundwater recharge using groundwater models. Water Supply. 19 (7): 2107-2115. https://doi.org/10.2166/ws.2019.091

Aggarwal, P.K., 2008. Global climate change and Indian agriculture: impacts, adaptation and mitigation. Indian $\mathbf{J}$ Sci. 78, 911-919.

Barron, J., Noel, S., Mikhail, M., 2009. Review of Agricultural Water Management Intervention Impacts at the Watershed Scale: a Synthesis Using the Sustainable Livelihoods Framework. Stockholm Environment Institute, Project Report - 2009.

Batchelor, C.H., Rama Mohan Rao, M.S., Manohar Rao, S., 2003. Watershed development: a solution to water shortages in semi-arid India or part of the problem? Land Use Water Resour. Res. 3, 1-10.

Boomiraj, K., Wani, S.P., Garg, K.K., Aggarwal, P.K., Palanisami, K., 2010. Climate change adaptation strategies for agro-ecosystem - a review. J. Agrometeorol. 12 (2): 145-160.

Bouma, J.A., Biggs, T.W., Bouwer, L.M., 2011. The downstream externalities of harvesting rainwater in semi-arid watersheds: an Indian case study. Agric. Water Manage. 98, 1162-1170.

Bump, J.B., Clemens, M.A., Demombynes, G., Haddad, L., 2012. Concerns about the Millennium Villages project report. The Lancet 379 (9830), 1945.

Clemens, M.A., Demombynes, G., 2011. When does rigorous impact evaluation make a difference? The case of the Millennium Villages. J. Dev. Effectiveness. 3 (3): 305-339.

Dass, A., Sudhishri, S., Lenka, N.K. and Patnaik, U. S. 2011. Runoff capture through vegetative barriers and planting methodologies to reduce erosion, and improve soil moisture, fertility and crop productivity in southern Orissa, India. Nutr. Cycl. Agroecosyst. 89, 4557. https://doi.org/10.1007/s10705010-9375-3

Fullen, M.A., Booth, C.A. 2006. Long-term grass ley set aside on sandy soils: A case study. J. Soil and Water Cons. 61, 236-241.

Garg, K.K., Karlberg, L., Barron, J., Wani, S.P., Rockstrom, J. 2012a. Assessing impact of agricultural water interventions at the Kothapally watershed, Southern India. Hydrol. Processes. 26 (3): 387-404.

Garg, K.K., Wani, S.P., Barron, J., Karlberg, L., Rockstrom, J. 2012b. Up-scaling potential impacts on water flows from agricultural water interventions: 
opportunities and trade-offs in the Osman Sagar catchment, Musi subbasin, India. Hydrol. Processes. http://dx.doi.org/10.1002/hyp.9516.

Glendenning, C.J., Ogtrop, F.F.V., Mishra, A.K., Vervoort, R.W. 2012. Balancing watershed and local scale impacts of rain water harvesting in India-a review. Agric. Water Manage. 107, 113.

Glendenning, C.J., Vervoort, R.W. 2011. Hydrological impacts of rainwater harvesting (RWH) in a case study catchment: The Arvari River, Rajasthan, India. Part2. Catchment scale impacts. Agric. Water Manage. 98, 715-730.

Joshi PK, Vasudha Pangare, Shiferaw B, Wani SP, Bouma J and Scott C. 2004. Socioeconomic and policy research on watershed management in India: Synthesis of past experiences and needs for future research. Global Theme on Agroecosystems Report no. 7. Patancheru, Andhra Pradesh, India: International Crops Research Institute for the Semi-Arid Tropics. $88 \mathrm{pp}$

Joshi, P.K., Jha, A.K., Wani, S.P., Sreedevi, T.K., Shaheen, F.A. 2008. Impact of watershed program and conditions for success: A meta-analysis approach. Global Theme on Agroecosystems Report no. 46. Patancheru, Andhra Pradesh, India; International Crops Research Institute for the Semi-Arid, Tropics. 24 pp.

Kumari, R., Singh, R., Singh, R.M., Tewari, R.K., Dhyani, S.K., Dev, I., Sharma, B., Singh, A.K. 2014. Impact of rainwater harvesting structures on water table behavior and groundwater recharge in Parasai-Sindh watershed of Central India. Indian Journal of Agroforestry. 16(2): 47-52.

Lenzi, M. A. 2002. Stream bed stabilization using boulder check dams that mimic step-pool morphology features in Northern Italy. Geomorphology. 45, 243-260

Madhu, M., Naik, B. S., Jakhar, P., Hombe Gowda, H. C., Adhikary, P. P., Gore, K. P.,Barman, D., and Naik, G.B. 2016. Comprehensive impact assessment of resource conservation measures in watershed of eastern region of India. Journal of Environmental Biology. 37(3): 391-398.

NAAS, 2009. State of Indian Agriculture. National Academy of Agricultural Science, New Delhi.

Ninan, K.N., and Lakshmikanthanthamma, S. 2001. Social Cost-Benefit Analysis of a Watershed Development Project in Karnataka. Royal Swedish Academy of Sciences. 30 (3): 157-161

Palanisami, K., and D.S. Kumar. 2009. Impacts of watershed development programmes: Experiences and Evidences from Tamil Nadu. Agricul. Econ. Rese. Rev. 22, 387-396

Reddy, V.R. 2000. Sustainable Watershed Management Institutional Approach. Economic and Political Weekly.

Rockstrom, J., Karlberg, L., Wani, S.P., Barron, J., Hatibu, N., Oweis, T., Bruggeman, A., Farahani, J., Qiang, Z., 2010. Managing water in rainfed agriculture - the need for a paradigm shift. Agric. Water Manage. 97, 543550.

Serveiss, V.B. 2002. Applying Ecological Risk Principles to Watershed Assessment and Management. Environ. Manage. 29, 145-154

Sharma, A., Thakur, P., 2007. Quantitative assessment of sustainability of proposed watershed development plans for Kharod watershed, Western India. J. Ind. Soc. Remote Sensing 35, 231-241.

Shi, Z.H., Ai, L., Fang, N.F. and Zhu,H.D. 2012. Modeling the impacts of integrated small watershed management 
on soil erosion and sediment delivery: A case study in the Three Gorges Area, China. J. Hydrol. 438-439: 156-167.

Sudhishri, S., Patnaik, U.S., Mahapatra, N. 2003. Rainfall-runoff modeling for Upper Kolab catchment of Orissa. J Appl Hydrol XVI(3):5-9

Vohland, K., Barry, B., 2009. A review of in situ rainwater harvesting (RWH) practices modifying landscape functions in African drylands. Agric. Ecosyst. Environ. 131, 119-127.

Wani, S.P., Pathak, P., Jangawad, L.S., Eswaran, H., Singh, P., 2003. Improved management of Vertisols in the semiarid tropics for increased productivity and soil carbon sequestration. Soil Use Manage. 217-222.

Wani, S.P., Rockstrom, J., Venkateswarlu, B., Singh, A.K., 2011. New paradigm to unlock the potential of rainfed agriculture in the semi-arid tropics. In: Lal, R., Stewart, B.A. (Eds.), World Soil Resources and Food Security. Advances in Soil Science. CRC Press, United Kingdom, pp. 419-469.

\section{How to cite this article:}

Manivannan, S., OPS. Khola, K. Kannan and Kasthuri Thilagam, V. 2021. Impact of Watershed Interventions on Biophysical and Ecosystem Services in Mettur Catchment of Tamil Nadu, India. Int.J.Curr.Microbiol.App.Sci. 10(01): 2402-2418. doi: https://doi.org/10.20546/ijcmas.2021.1001.279 